\title{
Toxicity and phytochemistry of eight species used in the traditional medicine of sul-mato-grossense, Brazil
}

\author{
L. A. B. M. Mendonça ${ }^{a *}$ (D), R. Matias ${ }^{b, c}$ (D), D. F. P. Zanella ${ }^{b}$ (D), K. R. A. Porto ${ }^{d}$ (D), \\ J. F. Guilhermino (D), D. L. Moreira ${ }^{\text {(D) }, A . R . ~ \text { Roel }^{a, b} \text { (iD, A. Pott }}$ (ID and C. M. E. Carvalho $^{a}$ \\ ${ }^{a}$ S-Inova Biotec, Programa de Pós-Graduação em Biotecnologia, Universidade Católica Dom Bosco - UCDB, \\ Avenida Tamandaré, 6000, Jardim Seminário, CEP 79117-010, Campo Grande, MS, Brasil \\ bPrograma de Pós-Graduação em Ciências Ambientais e Sustentabilidade, Universidade Católica Dom Bosco - UCDB, \\ Avenida Tamandaré, 6000, Jardim Seminário, CEP 79117-010, Campo Grande, MS, Brasil \\ 'Programa de Pós-Graduação em Ambiente e Desenvolvimento Regional, Universidade Anhanguera - UNIDERP, \\ Alexandre Herculano, 1400, Taquaral Bosque, CEP 79035-470, Campo Grande, MS, Brasil \\ dPrograma de Pós-Graduação em Biotecnologia e Biodiversidade, Universidade Federal de Mato Grosso do Sul - UFMS, \\ Rede Pró-Centro-Oeste, Avenida Costa e Silva, s/n, Pioneiros, CEP 79070-900, Campo Grande, MS, Brasil \\ 'Departamento de Ambiente e Saúde, Fundação Oswaldo Cruz - FIOCRUZ, José Abrão, 92, Jardim das Nações, \\ CEP 79074-460, Campo Grande, MS, Brasil \\ fDepartamento de Produtos Naturais, Instituto de Tecnologia Farmacêutica, Fundação Oswaldo Cruz - FIOCRUZ, \\ Avenida Brasil, 4365, Manguinhos, CEP 21040-900, Rio de Janeiro, RJ, Brasil \\ ${ }^{\text {g}}$ Conselho de Pesquisa, Programa de Pós-Graduação, Universidade Federal de Mato Grosso do Sul - UFMS, \\ Avenida Costa e Silva, s/n, Pioneiros, CEP 79070-900, Campo Grande, MS, Brasil \\ *e-mail: lmendoncanutri@gmail.com
}

Received: November 12, 2018 - Accepted: May 21, 2019 - Distributed: August 31, 2020

(With 2 figures)

\begin{abstract}
The Brazilian Cerrado has several botanical species for medicinal purposes used by traditional communities and many of these plants are not included in the list of Medicinal Plants Research Program of Central Medicines. The purpose of this study was the phytochemical screening and toxicology bioassay front of Brine shrimp L. of ethanolic extracts of eight species of plants used in folk medicine of Campo Grande, Mato Grosso do Sul, Brazil. The ethanolic extracts were submitted to phytochemical screening, determination of phenolic compounds and flavonoids. Toxicological assays were carried front of Brine shrimp according to standard methodology. The analysis TLC and HPLC-DAD confirmed the predominance of phenolic compounds and derivatives, specifically for the quercetin. The most toxic was the $C$. affinis DC. with death at all concentrations, the A. humile A. St. Hil. showed no mortality and the other species showed intermediate toxicity. The extracts of the investigated species are rich in phenolic compounds and derivatives, specifically quercetin, and feature toxicity between moderate to high, a fact that requires attention, since much of the traditional communities rely on herbal drugs in its raw form with preventive and curative purpose, meeting the basic health care.
\end{abstract}

Keywords: ethnopharmacology, Brazilian Cerrado, traditional communities, toxic plants, brine shrimp, secondary metabolites.

\section{Toxicidade e fitoquímica de oito espécies usadas na medicina tradicional sul- mato-grossense, Brasil}

\section{Resumo}

O Cerrado brasileiro possui diversas espécies botânicas com fins medicinais utilizadas por comunidades tradicionais e muitas dessas plantas não estão incluídas na lista do Programa de Pesquisa de Plantas Medicinais da Central de Medicamentos. O objetivo deste estudo foi a triagem fitoquímica e o bioensaio toxicológico frente ao Brine shrimp L. de extratos etanólicos de oito espécies de plantas utilizadas na medicina popular de Campo Grande, Mato Grosso do Sul. Os extratos etanólicos foram submetidos à triagem fitoquímica, determinação de compostos fenólicos e flavonoides. Os ensaios toxicológicos foram realizados frente ao Brine shrimp de acordo com a metodologia padrão. A análise de cromatografia de camada delgada e HPLC-DAD confirmou a predominância de compostos fenólicos e derivados, especificamente para a quercetina. O mais tóxico foi o C. affinis DC. com a morte em todas as concentrações, o A. humile A. St. Hil. não apresentou mortalidade e as demais espécies apresentaram toxicidade intermediária. Os extratos 
das espécies investigadas são ricos em compostos fenólicos e derivados, especificamente a quercetina e apresentam toxicidade entre moderada a alta, fato que requer atenção, pois grande parte das comunidades tradicionais conta com fitoterápicos em sua forma bruta com preventivo e finalidade curativa, atendendo aos cuidados básicos de saúde.

Palavras-chave: etnofarmacologia, Cerrado Brasileiro, comunidades tradicionais, plantas tóxicas, camarão de salmoura, metabólitos secundários.

\section{Introduction}

The Brazil is known for megabiodiversity botany, especially the Cerrado, which is the second ecological area of South America in area (Beuchle et al., 2015). It is one of the savannas with the greatest floral biodiversity, many employed in Brazilian traditional medicine (TM) (Baldauf and Santos, 2013).

The practice of TM in the country, specifically in the Cerrado of Mato Grosso do Sul, takes place under the strong influence of traditional communities (TC) (Oliveira et al., 2011) (pantaneiros, quilombolas, fisherman, indigenous people, family farmers and raizeiros), which holds one extensive knowledge about plants and their environment (Albuquerque et al., 2008). Among these are: Anacardium humile A. St. Hil. (Cajuzinho do Cerrado) and Maclura tinctoria (L.) D. Donex. Steud. (Moreira), followed by extract of Baccharis dracunculifolia DC. (Alecrim do Campo), Genipa americana L. (Jenipapo) and Smilax fluminensis Steud. (Japecanga), Campomanesia adamantium (Cambess.) O. Berg (Guavira), Cleome affines DC. (Espinho-de-Sogra) and Porophyllum ruderale (Jacq.) Cass. (Arnica do Campo). That have many applications and uses. These species, despite the use in TM, do not make the list of Medicinal Plants Research Program of Central Medicines, created for the use of complementary and alternative medicine, aiming to ensure the pharmacological potential, toxicological aspects, among others (Brasil, 2006).

Currently the Ministry of Health encourages the use in the Sistema Único de Saúde (SUS) Brazilian of 71 plant species (Brasil, 2009). However the use of plants with medicinal purpose deserves attention because much of the scientific research (Silva et al. 2019) set up to evaluate the pharmacological potential and not the toxicity (Bussmann et al. 2011).

Whereas the TC of Mato Grosso do Sul, Brazil, make use with frequency of the eight species mentioned informally and most of the time as the only form of treatment for the relief of painful processes and control some symptoms without any type of security in relation to the toxicological effects (Pott and Pott, 1994; Baldauf and Santos, 2013), it is appropriate to carry out phytochemical screening and toxicology bioassay front to Brine shrimp of eight plant species used in TM of Campo Grande, Mato Grosso do Sul, Brazil.

\section{Material and Methods}

\subsection{Collection and identification of plant species}

The plant material used was collected in Cerrado area in the city of Campo Grande, Mato Grosso do Sul, Brazil (Table 1). To collect and research purposes was obtained authorization for access to genetic resources of the "The Genetic Patrimony Board of Management (GPBM)" under the registration number 010579/2013-3.

The leaves of each species, and specifically stem and leaves of $S$. fluminensis after drying in an stove with air circulation $\left(40{ }^{\circ} \mathrm{C}\right)$ and grinding, were extracted with ethanol, by static maceration (temperature between $26^{\circ} \mathrm{C}$ to $30{ }^{\circ} \mathrm{C} \pm 1{ }^{\circ} \mathrm{C}$ ), followed by filtration and removal of solvent on a rotary evaporator. From the crude ethanol extracts were obtained of each species an ethanol solution at $20 \%$. These solutions were submitted to phytochemical analysis (Harborne, 1998), performed in triplicate and compared to the control sample (extracts at 20\%) and the readings of the results were made by observing the color change and precipitation of the filtrate according to Fontoura et al. (2015).

The crude extracts were used to quantify total phenols (TP), through Folin-Ciocalteu method with gallic acid (10 to $350 \mathrm{mg} \mathrm{mL}^{-1}$ ) as the standard $\left(Y=1.067 x-0.004 R^{2}=0.982\right)$. Flavonoids $(\mathrm{F})$ were evaluated by aluminum chloride method and as the standard the quercetin $\left(Y=0.0061 x-0.0633 R^{2}=0.999\right)$ (Do et al. 2014).

The confirmatory analysis of classes of chemical constituents of the ethanol extract of the investigated species were performed using TLC. To demonstrate the presence of flavonoids and phenol it was used quercetin and gallic acid respectively (1\%). Eluent systems, visualization of the bands (ultraviolet light irradiation: 254 and $365 \mathrm{~nm}$ ) and revelators were based on Wagner and Bladt (2009). The retention factors (Rf) of the bands formed in the areas of the chromatographic band patterns and the obtained ethanol extracts were calculated.

To confirm the chemical substances in the ethanol extracts of eight plants was also performed HPLC analysis by means

Table 1. List of species collected, location, voucher number (VN) and identification Extraction.

\begin{tabular}{|c|c|c|}
\hline Species & Location & $\mathbf{V N}$ \\
\hline A. humile* & S2026’20.64”' & 5558 \\
\hline B. dracunculifolia* & O54³2’26.78”' & 6766 \\
\hline P. ruderale* & & 8021 \\
\hline G. americana* & & 3079 \\
\hline S. fluminensis* & & 8296 \\
\hline C. affinis* & & 8264 \\
\hline M. tinctoria** & $\mathrm{S} 20^{\circ} 26^{\prime} 46^{\prime \prime} \mathrm{O} 54^{\circ} 43^{\prime} 30^{\prime \prime}$ & 25355 \\
\hline C. adamantium $* * *$ & $\begin{array}{l}\mathrm{S} 20^{\circ} 24^{\prime} 58.3^{\prime \prime} \\
\mathrm{O} 54^{\circ} 36^{\prime} 58.6^{\prime \prime}\end{array}$ & - \\
\hline
\end{tabular}

*Eloty Justina D. Schleder. **Arnildo Pott. ***Vali Joana Pott (Registration on request). 
of a liquid chromatograph SCL-10AVP ${ }^{\circledR}$ (Schimadzu, Japan) adjusted to a track of 220, 254 and $340 \mathrm{~nm}$ and equipped with pump LC 10AD; detector by spectrum scanning the ultraviolet DAD SPD M10A. The chromatographic column used was PR-18 (20 x 4.6 mm ID) $\left(\right.$ Merck $\left.^{\circledR}\right)$ and pre-column RP-18 $(250 \times 4.6 \mathrm{~mm}$ ID $5 \mathrm{um})$. The mobile phase was composed of the following solvents: (A) acetonitrile and (B) milli Q water acidified $\mathrm{pH} 3.5$ (glacial acetic acid). For the detection of polar compounds was considered the following schedule: acetonitrile $-10 \%$ ( 0 minutes), $90 \%$ (80 minutes) and 10\% (90 minutes) and for nonpolar compounds $\mathrm{H}_{2} \mathrm{O}-90 \%$ ( 0 minutes), $10 \%$ ( 80 minutes) and $90 \%$ (90 minutes) with flow of $1.0 \mathrm{~mL} /$ minute sample, considering a temperature of $40{ }^{\circ} \mathrm{C}$. The spectrum analysis was based on data from literature (Marston, 2007; Zeraik and Yariwake, 2010).

\subsection{Toxicological assay against Brine Shrimp}

The toxicity evaluation against Brine Shrimp was carried out according to the method of McLaughlin et al. (1993), expressed as Medium Lethal Concentration $\left(\mathrm{LC}_{50}\right)$, on which the extracts were diluted in dimethylsulfoxide (DMSO) (1\%) and saline solution, at concentrations 500, $250,125,62.5,31.2 \mu \mathrm{g} \mathrm{mL}^{-1}$.

\subsection{Statistical analysis}

Lethal concentrations $(10 \%, 50 \%$ and $90 \%)$ of the exposed population at each trial were determined using the Probit method, using Polo-PC program. The results the total content of TP and $\mathrm{F}$ of the samples were analyzed using ANOVA and Tukey post test, considering $(p<0.05)$ for both.

\section{Results}

3.1. Prospecting phytochemistry and chromatographic profile (Thin Layer Chromatography: TLC)

The phytochemical screening of extracts indicated higher diversity of classes of secondary metabolites in the species A. humile and M. tinctoria (9 classes), followed by $B$. dracunculifolia, G. americana and S. fluminensis (8 classes), C. adamantium, C. affinis (7 classes) and $P$. ruderale (6 classes) (Figure 1). Of the investigated classes only the phenolic compounds, flavonoids, tannins and steroids were detected in all species, with a higher frequency of phenolics and flavonoids (100\%).

The results of the analysis in TLC revealed the presence of quercetin in all samples except the C. adamantium, and for this species occurred the revelation of other flavonoids. Regarding the phenolic compounds just $B$. dracunculifolia and $P$. ruderale indicated $\mathrm{Rf}$ equal to the gallic acid and the revelators also indicated characteristic bands in the presence of other phenols (Table 2). These results are in agreement with the average of total phenols and flavonoids (Table 3), which were higher and statistically equal to the ethanol extract of G. americana and M. tinctoria, and statistically different from the other extracts.

According to the data expressed in the Table 3 , there was a significant variation in the contents of phenolic compounds between the extracts. The highest phenol content was found in the species G. americana and M. tinctoria which were statistically equal differing from other species. Followed by $A$. humile and $C$. adamantium (statistically equal) in sequence we have the $B$. dracunculifolia and with lower levels are the C. affinis, P. ruderale and S. fluminensis which also were statistically equal.

\section{Phytochemical analysis of ethanol extracts the species of the Cerrado, MS, Brazil}

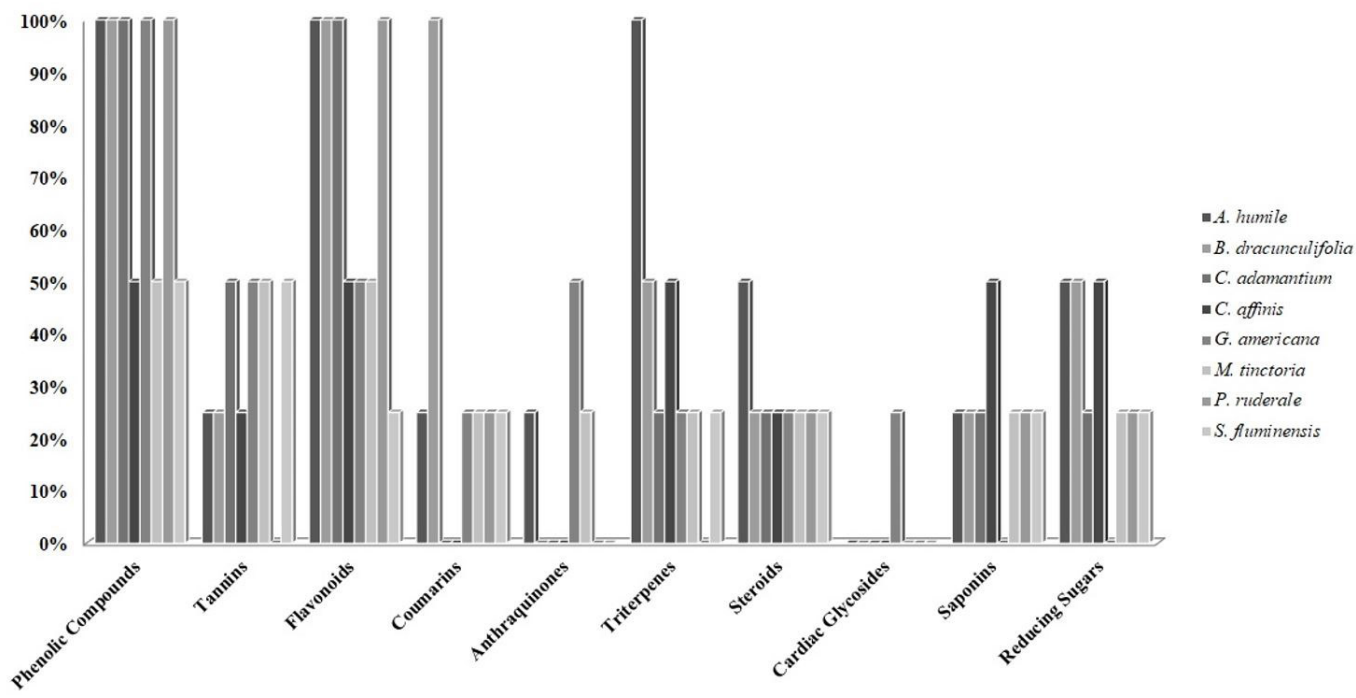

Figure 1. Phytochemical analysis and content total phenols (TP) and flavonoids (F) of ethanol extracts the species of the Cerrado, MS, Brazil. 
Table 2. Thin Layer Chromatography, retention factor, eluting, revelators and UV- visible spectrum sweep of the species of ethanol extracts the Cerrado, MS, Brazil.

\begin{tabular}{|c|c|c|c|c|}
\hline Species & \multicolumn{2}{|c|}{ A. humile } & \multicolumn{2}{|c|}{ B. dracunculifolia } \\
\hline Standard & Quercetin & Gallic Acid & Quercetin & Gallic Acid \\
\hline RF Standard & 0.25 & 0.37 & 0.68 & 0.35 \\
\hline RF Sample & 0.25 & 0.51 & 0.68 & 0.35 \\
\hline Species & \multicolumn{2}{|c|}{ C. adamantium* } & \multicolumn{2}{|c|}{ C. affinis* } \\
\hline Standard & Quercetin & Gallic Acid & Quercetin & Gallic Acid \\
\hline RF Standard & 0.39 & 0.51 & 0.44 & 0.36 \\
\hline RF Sample & 0.25 & - & 0.44 & - \\
\hline Species & \multicolumn{2}{|c|}{ G. americana* } & \multicolumn{2}{|c|}{ M. tinctoria } \\
\hline Standard & Quercetin & Gallic Acid & Quercetin & Gallic Acid \\
\hline RF Standard & 0.35 & 0.35 & 0.57 & 0.40 \\
\hline RF Sample & 0.32 & - & 0.51 & 0.32 \\
\hline Species & \multicolumn{2}{|c|}{ P. ruderale } & \multicolumn{2}{|c|}{ S. fluminensis* } \\
\hline Standard & Quercetin & Gallic Acid & Quercetin & Gallic Acid \\
\hline RF Standard & 0.13 & 0.60 & 0.51 & 0.54 \\
\hline RF Sample & 0.60 & 0.51 & 0.51 & - \\
\hline
\end{tabular}

Eluentes: $\mathrm{CHCl3:MeOH}$ : Chloroform/Methanol (7:3), used for A. humile in the elution of quercetin, Hex./Et.AC./ MeOH: Hexane/Ethyl Acetate/Methanol (7:2:1), used for specie A in the elution of gallic acid, $\mathrm{CH} 2 \mathrm{Cl} 2 \mathrm{MeOH}$ : Dichloromethane/Methanol (9:1), used used for species B. dracunculifolia, C. adamantium, C. affinis, G. americana, M. tinctoria, P. ruderale, and S. fluminensis in the elution of quercetin and gallic acid; Revelators: Cit. Ac./ UV: Citric Acid/Ultra Violet, F. Clor:: Ferric. Chloride, used for revelation of species of the study. *Absence of bands in the standard region undisclosed.

Table 3. Total content of the total phenols and flavonoids, retation time (HPLC-DAD) and maximum wavelength in the UV-visible region of the species of the Cerrado, MS, Brazil.

\begin{tabular}{|c|c|c|c|c|}
\hline Species & ${ }^{*} \mathrm{TP}\left(\mathrm{mg} \mathrm{g}^{-1}\right)$ & *F (mg g $\left.{ }^{-1}\right)$ & RT & $\lambda_{\max }$ \\
\hline \multirow[t]{2}{*}{ A } & $332.63 \pm 4.65^{\mathrm{a}}$ & $115.19 \pm 2.44^{\mathrm{a}}$ & 4.80 & 254 \\
\hline & & & 7.70 & \\
\hline \multirow[t]{3}{*}{ B } & $260.08 \pm 1.84^{b}$ & $126.08 \pm 3.45^{\mathrm{a}}$ & 19.0 & 310 \\
\hline & & & 24.1 & 290 \\
\hline & & & 41.9 & $235,254,340$ \\
\hline \multirow[t]{2}{*}{$\mathrm{C}$} & $321.96 \pm 3.84^{\mathrm{a}}$ & $122.85 \pm 2.53^{\mathrm{a}}$ & 22.7 & 254 \\
\hline & & & 23.2 & \\
\hline \multirow[t]{2}{*}{$\mathrm{D}$} & $124.57 \pm 2.13^{c}$ & $56.58 \pm 1.77^{\mathrm{b}}$ & 2.80 & 254 \\
\hline & & & 3.90 & \\
\hline \multirow[t]{3}{*}{$\mathrm{E}$} & $456.39 \pm 10.17^{\mathrm{d}}$ & $182.83 \pm 0.46^{\mathrm{c}}$ & 19.9 & 340 \\
\hline & & & 20.8 & \\
\hline & & & 22.9 & 254 \\
\hline \multirow[t]{4}{*}{ F } & $425.46 \pm 2.82^{\mathrm{d}}$ & $177.28 \pm 3.58^{c}$ & 11.6 & 340 \\
\hline & & & 12.2 & \\
\hline & & & 13.9 & \\
\hline & & & 63.6 & 254 \\
\hline $\mathrm{G}$ & $150.18 \pm 3.84^{c}$ & $120.19 \pm 1.24^{\mathrm{a}}$ & 22.2 & 254,340 \\
\hline $\mathrm{H}$ & $145.91 \pm 3.13^{\mathrm{c}}$ & $49.23 \pm 1.91^{\mathrm{b}}$ & 25.5 & 254,340 \\
\hline
\end{tabular}

A: A. humile, B: B. dracunculifolia, C: C. adamantium, D: C. affinis, E: G. americana, F: M. tinctoria, G: P. ruderale, $\mathrm{H}$ : S. fluminensis. Similar letters do not differ statistically. ${ }^{*}$ Mean $\pm \mathrm{SD} .(\mathrm{p}<0.01)$.

The flavonoids followed the same standards only for $G$. americana and $M$. tinctoria which presented higher levels and were statistically equal, followed by $A$. humile, $B$. dracunculifolia, C. adamantium and P. ruderale. And with lower levels of flavonoids are the C. affinis e S. fluminensis.

These results were also confirmed by analysis of the chromatographic profile in the HPLC of the etanolic extracts of the respective plants, using gradient analysis conditions and two wavelengths (254 and $340 \mathrm{~nm}$ ) in the analysis. A similar chromatographic profile was observed for the species $B$. dracunculifolia, P. ruderale, S. fluminensis and G. americana (Figure 2) in these two monitored wavelengths, which suggests the presence of benzopyran skeleton characteristic of flavonoid. 

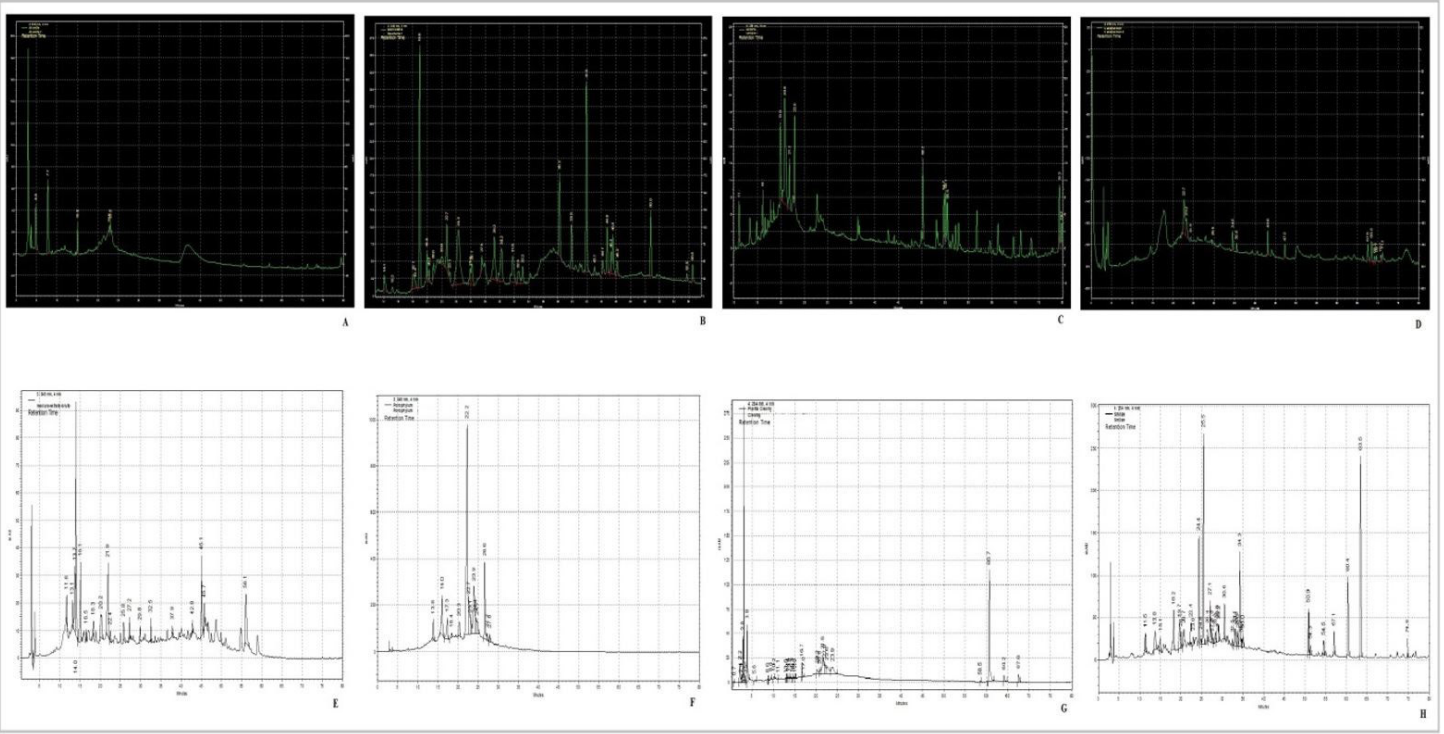

Figure 2. Chromatographic Profile by HPLC-DAD of the species of ethanol extracts the Cerrado, MS, Brazil. Chromatograms of: (A) Anacardium humile; (B) Baccharis dracunculifolia; (C) Genipa americana; (D) Campomanesia adamantium; (E) Maclura tinctoria; (F) Porophyllum ruderale; (G) Cleome affinis; (H) Smilax fluminensis. Chromatographic conditions: column RP-18 (20 mm $\times 4.6$ ID) da Merck ${ }^{\circledR}$ and pre-column RP-18 (250 mm $\left.\times 4.6 \mathrm{ID}, 5 \mu \mathrm{m}\right)$. Mobile phase: polar compounds: acetonitrile - 10\% (0 minutes), $90 \%$ (80 minutes) e 10\% (90 minutes), apolar compounds: $\mathrm{H}_{2} \mathrm{O}-90 \%$ ( 0 minutes), $10 \%$ (80 minutes) e $90 \%$ (90 minutes) with a flow of $1.0 \mathrm{~mL} /$ minutes, $40^{\circ} \mathrm{C},(\lambda 200-400 \mathrm{~nm})$.

The species A. humile, C. adamantium and C. affinis showed similarity in the chromatographic profile only in the wavelength of $254 \mathrm{~nm}$, characteristic of phenolic groups. Specifically for A. humile it was evident in the chromatogram that of the peaks observed at the times of 4.8 minutes and 7.7 minutes, are indicative of anarcadic acid common for this species. Regarding the M. tinctoria of the two monitored wavelengths, a peak was observed at $340 \mathrm{~nm}$, which indicates that this extract is rich in compounds of medium polarity.

\subsection{Toxicological assay against Brine shrimp}

Of the species studied the highest toxicity presented was $C$. affinis, followed by $S$. fluminensis, M. tinctoria, P. ruderale, C. adamantium, B. dracunculifolia and G. americana. It should be noted that the species A. humile was not considered feasible, as that showed no mortality (Table 4).

\section{Discussion}

The anacardiaceas, as well as A. humile are recognized for having anacardic acid whose absorption occurs between 280 and $320 \mathrm{~nm}$ at retention times of 4.8 and 7.7 minutes. In recent work with the leaves of the species it was observed the presence of monoene and diene anacardic acid at the retention times of 3.8 and 4.5 minutes, indicating that the extract utilized in the Brine shrimp assay also it is rich in phenolic lipids (Matias et al., 2013).

The HPLC spectre confirmed the diversity of phenolic compounds and flavonoids from $B$. dracunculifolia in the
Table 4. Lethal concentrations $\left(\mathrm{LC}_{50}\right)$ in $\mu \mathrm{g} \mathrm{mL}^{-1}$ of ethanol extracts the species of the Cerrado.

\begin{tabular}{lccc}
\hline & & \multicolumn{2}{c}{$\begin{array}{c}\text { Confidence Interval } \\
\text { S5\% }\end{array}$} \\
\cline { 3 - 4 } \multicolumn{1}{c}{ Species } & LC $_{\mathbf{5 0}}$ & $\begin{array}{c}\text { Lower } \\
\text { Limit }\end{array}$ & $\begin{array}{c}\text { Upper } \\
\text { Limit }\end{array}$ \\
\hline A. humile & $*$ & $*$ & $*$ \\
B. dracunculifolia & 347.00 & 202.00 & 595.00 \\
C. adamantium & 67.00 & 12.00 & 366.00 \\
C. affinis & $*$ & $* *$ & $* *$ \\
G. americana & 383.00 & 205.00 & 710.00 \\
M. tinctoria & 44.71 & 14.93 & 133.84 \\
P. ruderale & 63.94 & 36.32 & 112.56 \\
S. fluminensis & 33.43 & 20.70 & 53.98 \\
\hline
\end{tabular}

*No mortality. **Too high toxicity.

length $\lambda_{\max }$ between $254 \mathrm{~nm}$ to $340 \mathrm{~nm}$ in the retention times of 12.0 to 56.6 minutes. These findings are consistent with data from the literature that point out that in the retention times up to 28 minutes are the phenolics compounds and above this value the flavonoids and premilates (Sousa et al., 2009). The phenolics compounds and derivatives have great importance in obtaining green propolis produced by Apis melifera in Brazil (Bastos et al., 2011).

The $C$. adamantium, common in the Cerrado region, is already known to be rich in flavonoids and glycoflavonoids, and it is the chromatographic profile in TLC (Table 3) and in HPLC at $254 \mathrm{~nm}$ confirm that the etanolic extract of the leaves of these species has flavonoids at retention times 
22.7 minutes, common for flavones in 34.5 minutes, the latter being common for chacons (Viscardi et al., 2016).

The G. americana is one rubiaceae recognized for presented iridoids, but no peakes were observed below 8 minutes (Ono et al., 2005). The quercetin evidenced in TLC is also present in the chromatogram (Figure 1) in the retention time of 11.1 minutes, above this value are found other polyphenols (Huber et al., 2007).

The species of the genre Maclura, both from the east and the west are recognized by use in the folk medicine, specifically in the Brazilian folk medicine, which are used by the indigenous people in the treatment of cough, property attributed to flavonoids and isoflavones (Orhan et al., 2009), as detected in ethanolic extract in TLC and HPLC.

The $P$. ruderale, Brazilian arnica, is composed of essential oils, phenolic compounds, flavonoids, tannins, alkaloids, terpenes, saponins and is recognized for having thiophene derivatives. In the HPLC assay it was possible to show that the peaks at the retention times of 11.8, 15.9 and 22.2 are characteristic of derivatives of thiophene. The family asteraceae is recognized by terthiophene and polyenes that have strong activity against microorganisms, viruses, tumor cells and leishmaniose (Ciofalo et al., 1996; Takahashi et al., 2011).

For the ethanolic extract of S. fluminensis the presence of phenolic compounds and flavonoids was detected, as expected (Takahashi et al., 2011). HPLC analysis was an important tool to characterize the presence of two glycoflavonoids of the quercentin group at retention times 25.5 and 34.3 minutes at a wavelength of $254 \mathrm{~nm}$, these results are consistent with those found by Petrica et al. (2014) at retention times of 32.0 and 25.8 minutes at a wavelength of $254 \mathrm{~nm}$.

The chemical profile showed that all ethanolic extracts contains mainly flavonoids and phenolic compounds, particularly quercetin. For these groups are mainly pointed out anti-inflammatory and antioxidant activities (Do et al., 2014). This information justifies the use of these eight species in TM sul-mato-grossense, since the Cerrado's natural resources are vast, and has several TC distributed throughout the country, and due to the geographical extent of the Mato Grosso do Sul state, these communities are relatively isolated. Therefore, these populations have developed special ways of life with strong relationship with natural resources, and for this reason the use of plants for medicinal purposes has enabled rural TC use this therapeutic arsenal in multiple treatments.

In the Cerrado Region and Pantanal is in common use by TM the species: $A$. humile, whose tea leaves is used as antidiarrheal; $C$. affinis used as a stomach tonic against gases, headache and decongestant; $G$. americana acts as anti-inflammatory and anti-diarrheal; $M$. tinctoria is already healing and $S$. fluminensis purifying and diuretic (Pott and Pott, 1994).

The empirical knowledge of the species was eventually expanded to major centers such as raizeiros who are mainly located in the Municipal Market of Campo Grande, Mato Grosso do Sul, which is considered an area of great commercial activity, frequented not only by the local community, but also by tourists both national and international. This TC besides market also carries some therapeutic indications and forms of preparation. Among the species most commercialized by raizeiros are the leaves of $B$. dracunculifolia as anti-rheumatic and anticatarrhal; and M. tinctoria sheets employed as wound healing, treatment of syphilis, rheumatism and as an astringent (Ustulin et al., 2009).

Specifically in Campo Grande quilombola São Benedito community (Tia Eva) makes use of species A. humile as anti-inflammatory and B. dracunculifolia with cardiovascular purposes (Schardong and Cervi, 2000). Since the $C$. adamantium, well distributed in the Cerrado, the leaves have anti-inflammatory properties, antidiarrhoeal and anti-septic urinary tract and treatment of influenza (Lorenzi and Lacerda, 2006).

The $P$. ruderale it is one of the regional native medicinal plants most used by the rural population and settlers, the tea from its leaves is used to treat strep throat, hepatitis and stomach problems, uterine and testicular (Bratti et al., 2013).

This scenario demonstrates that the studied species have medicinal properties based on empirical knowledge and the phytochemical screening showed that traditional employment can be sustained by the presence of phenols and derivatives. Corroborate these data Silva et al. (2010) who carried out phytochemical analysis in 18 species of the Cerrado, noting the prevalence of phenols and flavonoids.

In a complementary manner, by associating the chemical profile of eight plants with the corresponding $\mathrm{LC}_{50}$ obtained against Brine shirmp, that can be correlated with other biological activities (Barth et al., 2018), it was observed that among species with higher diversity and predominance of flavonoids and phenolic compounds, with higher $\mathrm{LC}_{50}$ values are the extract of $A$. humile, G. americana, $B$. dracunculifolia, C. adamantium, and species with intermediate values $P$. ruderale and $M$. tinctoria, meaning less toxicity. With lower $\mathrm{LC}_{50}$ values are the extracts of C. affinis and $S$. fluminensis according to McLaughlin et al. (1993), which has low toxicity $\left(\mathrm{LC}_{50}\right.$ greater than $\left.500 \mu \mathrm{g} \mathrm{mL}^{-1}\right)$; moderate (between 100 and $500 \mu \mathrm{g} \mathrm{mL}^{-1}$ ) and very toxic (below $100 \mu \mathrm{g} \mathrm{mL}^{-1}$ ).

Based on these facts, the extract with higher toxicity was $C$. affinis, which indicates high mitotic activity of this plant. However, the toxicity found, despite the variety of secondary metabolites may be attributed to the synergism which enhances one of the classes present in the extract as saponins. Associated to this class, hemolysis processes which occur by the affinity of the aglycone (steroidal or triterpene nucleus) with cholesterol in cell membranes (Karabaliev and Kochev, 2003), and the hydrophilic moiety composed of one or more chain sugars within the cell acts by inhibiting the enzymatic action of amino acid residues by polar region (Simões et al., 2010).

It is common to use plant extracts in toxicity analyzes with Brine shirmp and among the mechanisms proposed are protein denaturation, enzyme inhibition and disintegration of the membrane causing a probable interaction between 
the components of the extract, resulting in synergy (Thoison et al., 2004).

Chemical and biological results demonstrated that the toxicity of the extracts studied deserves attention, especially C. affinis, since the use of these plants for TC is significant, necessitating the development of experimental tests in vitro and in vivo to determine the acute toxicity and chronic.

\section{Conclusion}

This study demonstrated that all the investigated species extracts are rich in phenolic compounds and derivatives. The extract with the highest toxicity was $C$. affinis, which may be related to the synergistic effects of the contents of secondary metabolites present.

The assessment of the toxicological aspects is essential in view of the significant species studied by use of TC, in order not to cause undesirable toxic effects. The ethnopharmacological the information in this study provided important support for studies of phytochemical and toxicological testing to guarantee strategies for using of these plants as efficacy and lack of toxicity.

\section{Acknowledgements}

This work was supported by Conselho Nacional de Desenvolvimento Científico e Tecnológico (CNPq); Instituto Nacional de Áreas Úmidas (INAU), Centro de Pesquisa do Pantanal (CPP) [704792/2009], Fundação de apoio ao Desenvolvimento do Ensino, Ciência e Tecnologia de Mato Grosso do Sul (FUNDECT) [30113.432.2350.28042014] and Coordenação de Aperfeiçoamento de Pessoal de Nível Superior (CAPES) [00269746]. CMEC conceived the idea and supervised the study design. RM LABMM and DFPZ conducted experiments for obtaining extracts and performed all chemical analyzes. JFG AP and DLM were responsible for part of the collection of botanical material, identifying and obtaining registration in Genetic Heritage Board of Management (REGN). KRAP LABMM ARR and DFPZ conducted biological experiments.

\section{References}

ALBUQUERQUE, U.P., LUCENA, R.F.P. and CUNHA, L.V.F.C., 2008. Métodos e técnicas na pesquisa etnobotânica. 2nd ed. Recife: Nupeea.

BALDAUF, C. and SANTOS, F.A.M., 2013. Ethnobotany, traditional knowledge, and diachronic changes in non-timber forest products management: a case study of Himatanthus drasticus (Apocynaceae) in the Brazilian Savanna. Economic Botany, vol. 67, no. 2, pp. 110-120. http://dx.doi.org/10.1007/ s12231-013-9228-5.

BARTH, E.F., PINTO, L.S., DILELI, P., BIAVATTI, D.C., SILVA, Y.L., BORTOLUCCI, W., GAZIM, Z.C., TAKEMURA, O.S., ROMAGNOLO, M.B. and LAVERDE-JÚNIOR, A., 2018. Biological screening of extracts from leaf and stem bark of Croton floribundus Spreng. (Euphorbiaceae). Brazilian Journal of Biology = Revista Brasileira de Biologia, vol. 78, no. 4, pp. 601-608. http://dx.doi.org/10.1590/1519-6984.166522. PMid:29319750.
BASTOS, E.M.A.F., SANTANA, R.A., CALAÇA-COSTA, A.G.F. and THIAGO, P.S., 2011. Interaction between Apis mellifera L. and Baccharis dracunculifolia DC, that favours green propolis production in Minas Gerais. Brazilian Journal of Biology $=$ Revista Brasileira de Biologia, vol. 71, no. 3, pp. 727-734. http://dx.doi.org/10.1590/S1519-69842011000400018. PMid:21881797.

BEUCHLE, R., GRECCHI, R.C., SHIMABUKURO, Y.E., SELIGER, R., EVA, H.D., SANO, E. and ACHARD, F., 2015. Land cover changes in the Brazilian Cerrado and Caatinga biomes from 1990 to 2010 based on a systematic remote sensing sampling approach. Applied Geography, vol. 58, pp. 116-127. http://dx.doi. org/10.1016/j.apgeog.2015.01.017.

BRASIL. Ministério da Saúde, 2006. Decreto $n^{\circ}$ 5.813, de 22 de junho de 2006. Política Nacional de Plantas Medicinais e Fitoterápicos. Diário Oficial da República Federativa do Brasil, Brasília. p. 136.

BRASIL. Ministério da Saúde, 2009. Programa nacional de plantas medicinais e fitoterápicos. 1. ed. Brasília: Secretaria de Ciência, Tecnologia e Insumos Estratégicos, Departamento de Assistência Farmacêutica e Insumos Estratégicos. 60 p.

BRATTI, C., VIEIRA, M.C., ZÁRATE, N.A.H., OLIVEIRA, A.P.A., MARAFIGA, B.G. and FERNANDES, S.S.L., 2013. Levantamento de plantas medicinais nativas da Fazenda Azulão em Dourados-MS. Revista Brasileira de Plantas Medicinais, vol. 15 , no. 4, pp. 675-683. http://dx.doi.org/10.1590/S151605722013000500008 .

BUSSMANN, R.W., MALCA, G., GLENN, A., SHARON, D., NILSEN, B., PARRIS, B., DUBOSE, D., RUIZ, D., SALEDA, J., MARTINEZ, M., CARILLO, L., WALKER, K., KUHLMAN, A. and TOWNESMITH, A., 2011. Toxicity of medicinal plants used in traditional medicine in Northern Peru. Journal of Ethnopharmacology, vol. 137, no. 1, pp. 121-140. http://dx.doi.org/10.1016/j.jep.2011.04.071. PMid:21575699.

CIOfAlO, M., PETRUSO, S. and SCHILlaCI, D., 1996. Quantitative assay of photoinduced antibiotic activities of naturally occurring 2,2':5'2"'-terthiophenes. Planta Medica, vol. 62, no. 4, pp. 374-375. http://dx.doi.org/10.1055/s-2006-957912. PMid:8792675.

DO, Q.D., ANGKAWIJAYA, A.E., TRAN-NGUYEN, P.L., HUYNH, L.H., SOETAREDJO, F.E., ISMADJI, S. and JU, Y.H., 2014. Effect of extraction solvent on total phenol content, total flavonoid content, and antioxidant activity of Limnophila aromatica. Journal of Food and Drug Analysis, vol. 22, no. 3, pp. 296-302. http://dx.doi.org/10.1016/j.jfda.2013.11.001. PMid:28911418.

FONTOURA, F.M., MATIAS, R., LUDWIG, J., OLIVEIRA, A.K.M., BONO, J.A.M., MARTINS, P.F.R.B., CORSINO, J. and GUEDES, N.M.R., 2015. Seasonal effects and antifungal activity from bark chemical constituents of Sterculia apetala (Malvaceae) at Pantanal of Miranda, Mato Grosso do Sul, Brazil. Acta Amazonica, vol. 45, no. 3, pp. 283-292. http://dx.doi. org/10.1590/1809-4392201500011.

HARBORNE, A.B., 1998. Phytochemical methods a guide to modern techniques of plant analysis. Netherlands: Springer Science \& Business Media, $302 \mathrm{p}$.

HUBER, L.S., RODRIGUEZ-AMAYA, D.B. and RODRIGUES, M.I., 2007. Otimização e validação de metodologia analítica para determinação de flavonóis e flavonas por CLAE em hortaliças. Revista do Instituto Adolfo Lutz, vol. 66, no. 2, pp. 142-151. 
KARABALIEV, M. and KOCHEV, V., 2003. Interaction of solid supported thin lipid films with saponin. Sensors and Actuators $B$ Chemical, vol. 88, no. 1, pp. 101-105. http://dx.doi.org/10.1016/ S0925-4005(02)00311-8.

LORENZI, H. and LACERDA, M., 2006. Frutas brasileiras e exóticas cultivadas (de consumo in natura). 1nd ed. São Paulo: Editora Plantarum, $640 \mathrm{p}$.

MARSTON, A., 2007. Role of advances in chromatographic techniques in phytochemistry. Phytochemistry, vol. 68, no. 22-24, pp. 2786-2798. http://dx.doi.org/10.1016/j.phytochem.2007.08.004. PMid:17931672.

MATIAS, R., ROEL, A.R., ANDRADE-FILHO, N.N., SCHELEDER, E.E.J.D., YASUNAKA, D.S. and CARDOSO, C.A.L., 2013. Controle de mosca-branca em mandioca cultivada em casa de vegetação tratada com extrato de Anacardium humile (Anacardiaceae). Bioscience Journal, vol. 29, no. 6, pp. 1815-1822.

MCLAUGHLIN, J.L., CHANG, C. and SMITH, D.L., 1993. Simple bench-top bioassays (brine shrimp and potato discs) for the discovery of plant antitumor compounds. In: A.D. KINGHRN and M.F. BALANDRIN, eds. Human medicinal agents from plants. 1nd ed. Washington: American Chemical Society, pp. 112-137. http://dx.doi.org/10.1021/bk-1993-0534.ch009.

OLIVEIRA, A.K.M., OLIVEIRA, N.A., RESENDE, U.M. and MARTINS, P.F.R.B., 2011. Ethnobotany and traditional medicine of the inhabitants of the Pantanal Negro sub-region and the raizeiros of Miranda and Aquidauna, Mato Grosso do Sul, Brazil. Brazilian Journal of Biology $=$ Revista Brasileira de Biologia, vol. 71, no. 1, suppl. 1., pp. 283. http://dx.doi.org/10.1590/ S1519-69842011000200007. PMid:21537601.

ONO, M., UENO, M., MASUOKA, C., IKEDA, T. and NOHARA, T., 2005. Iridoid glucosides from the fruit of Genipa americana. Chemical \& Pharmaceutical Bulletin, vol. 53, no. 10, pp. 13421344. http://dx.doi.org/10.1248/cpb.53.1342. PMid:16204999.

ORHAN, I., SENOL, F.S., KARTAL, M., DVORSKÁ, M., ZEMLICKA, M., SMEJKAL, K. and MOKRÝ, P., 2009. Cholinesterase inhibitory effects of the extracts and compounds of Maclura pomifera (Rafin.) Schneider. Food and Chemical Toxicology, vol. 47, no. 8, pp. 1747-1751. http://dx.doi.org/10.1016/j. fct.2009.04.023. PMid:19394400.

PETRICA, E.E.A., SINHORIN, A.P., SINHORIN, V.D.G. and JÚNIOR, G.M.V., 2014. First phytochemical studies of japecanga (Smilax fluminensis) leaves: flavonoids analysis. Revista Brasileira de Farmacognosia, vol. 24, no. 4, pp. 443-445. http://dx.doi. org/10.1016/j.bjp.2014.07.020.

POTT, A. and POTT, V.J., 1994. Plantas do Pantanal. 1nd ed. Brasília: Editora Embrapa. 320 p.

SCHARDONG, R.M.F. and CERVI, A.C., 2000. Estudos etnobotânicos das plantas de uso medicinal e místico na comunidade de São Benedito, Bairro São Francisco, Campo Grande, MS, Brasil. Acta Biológica Paranaense, vol. 29, no. 1-4, pp. 187-217. http://dx.doi.org/10.5380/abpr.v29i0.591.
SILVA, F.R.G., MATIAS, T.M.S., SOUZA, L.I.O., MATOSROCHA, T.J., FONSECA, S.A., MOUSINHO, K.C. and SANTOS, A.F., 2019. Phytochemical screening and in vitro antibacterial, antifungal, antioxidant and antitumor activities of the red propolis Alagoas. Brazilian journal of biology $=$ Revista brasleira de biologia, vol. 79, no. 3, pp. 452-459. PMid:30379200.

SILVA, N.L.A., MIRANDA, F.A.A. and CONCEIÇÃO, G.M., 2010. Triagem fitoquímica de plantas de Cerrado, da área de proteção ambiental municipal do Inhamum, Caxias, Maranhão. Scientia Plena, vol. 6, no. 2, pp. 1-17.

SIMÕES, C.M.O., SCHENKEL, E.P., GOSMANN, G., MELLO, J.C.P., MENTZ, L.A. and PETROVICK, P.R., 2010. Farmacognosia: da planta ao medicamento. 6nd ed. Florianópolis: Universidade Federal de Santa Catrina.

SOUSA, J.P.B., SILVA-FILHO, A.A., BUENO, P.C.P., GREGÓRIO, L.E., FURTADO, N.A., JORGE, R.F. and BASTOS, J.K., 2009. A validated reverse-phase HPLC analytical method for the quantification of phenolic compounds in Baccharis dracunculifolia. Phytochemical Analysis, vol. 20, no. 1, pp. 24-32. http://dx.doi. org/10.1002/pca.1087. PMid:18752260.

TAKAHASHI, H.T., NOVELLO, C.R., UEDA-NAKAMURA, T., DIAS FILHO, B.P., MELLO, J.C.P. and NAKAMURA, C.V., 2011. Thiophene derivatives with antileishmanial activity isolated from aerial parts of Porophyllum ruderale (Jacq.) Cass. Molecules, vol. 16, no. 5, pp. 3469-3478. http://dx.doi.org/10.3390/ molecules16053469. PMid:21522080.

THOISON, O., SÉVENET, T., NIEMEYER, H.M. and RUSSELL, G.B., 2004. Insect antifeedant compounds from Nothofagus dombeyi and N. pumilio. Phytochemistry, vol. 65, no. 14, pp. 2173-2176. http://dx.doi.org/10.1016/j.phytochem.2004.04.002. PMid:15279992.

USTUliN, M., FIGUEIREDO, B.B., TREMEA, C., POTT, A., POTT, J.V., BUENO, N.R. and CASTILHO, R.O., 2009. Plantas medicinais comercializadas no Mercado Municipal de Campo Grande-MS. Revista Brasileira de Farmacognosia, vol. 19 , no. 3, pp. 805-813. http://dx.doi.org/10.1590/S0102$695 \times 2009000500026$

VISCARDI, D.Z., OLIVEIRA, V.S., ARRIGO, J.S., PICCINELLI, A.C., CARDOSO, C.A.L., MALDONADE, I.R., KASSUYA, C.A.L. and SANJINEZ-ARGANDOÑA, E.J., 2016. Anti-inflammatory, and antinociceptive effects of Campomanesia adamantium microencapsulated pulp. Revista Brasileira de Farmacognosia, vol. 27, no. 2, pp. 220-227. http:// dx.doi.org/10.1016/j.bjp.2016.09.007.

WAGNER, H. and BLADT, S., 2009. Plant drug analysis: a thin layer chromatography atlas. 2nd ed. New York: Springer.

ZERAIK, M.L. and YARIWAKE, J.H., 2010. Quantification of isoorientin and total flavonoids in Passiflora edulis fruit pulp by HPLC-UV/DAD. Microchemical Journal, vol. 96, no. 1, pp. 86-91. http://dx.doi.org/10.1016/j.microc.2010.02.003. 